\title{
HUBUNGAN STATUS GIZI DENGAN PERKEMBANGAN ANAK USIA 3 - 5 TAHUN DI POSYANDU TAWANGSARI MOJOSONGO JEBRES SURAKARTA
}

\author{
Lilik Hanifah $^{1}$ Danik Riawati $^{2}$ \\ Email : lilik_hanifah84@yahoo.com \\ Prodi D III Kebidanan STIKES Mamba'ul 'Ulum Surakarta \\ Jl. Ring Road Utara KM 03, Tawangsari, Mojosongo, Jebres, Surakarta
}

\begin{abstract}
Abstrak
Masa balita yang disebut dengan golden periode, merupakan masa pertumbuhan dan perkembangan yang paling pesat pada otak manusia, masa ini otak bersifat plastis dibandingkan dengan orang dewasa sehingga balita sangat terbuka dan peka dalam menerima berbagai macam pembelajaran dan pengayaan baik bersifat positif maupun negatif. Oleh karena itu kita harus memberi masukan dan nilai-nilai yang postiif, menghindari masukan yang bersifat negatif dan sedapat mungkin memberikan asupan gizi yang adekuat, memberikan stimulasi yang baik dan benar, serta memberikan pelayanan kesehatan yang terbaik bagi anak, sehingga tercapai tumbuh kembang yang optimal. ${ }^{1}$ Tujuan penelitian ini adalah untuk mengetahui hubungan status gizi dengan perkembangan anak usia 3 - 5 Tahun di Posyandu Tawangsari Mojosongo Jebres Surakarta.

Jenis penelitian ini adalah observasional analitik dengan rancangan cross sectional.Populasi penelitian adalah anak usia 3 - 5 tahun di Posyandu Tawangsari, Mojosongo, Jebres, Surakarta. Sampel penelitian sebanyak 40 anak dengan teknik simple random sampling. Analisis data menggunakan chi square.

Hasil penelitian menunjukkan bahwa ada hubungan status gizi dengan perkembangan pada anak usia 3 - 5 tahun. Semakin tinggi status gizi anak semakin meningkat pula perkembangan anak. Hubungan tersebut secara statistik signifikan $(\mathrm{OR}=2,785)$. Nilai $p$ value adalah 0.000 berarti terdapat hubungan status gizi dengan perkembangan pada anak usia $3-5$ tahun.
\end{abstract}

Kata Kunci : status gizi, perkembangan anak.

\section{Pendahuluan}

Masa balita yang disebut dengan golden periode, merupakan masa pertumbuhan dan perkembangan yang paling pesat pada otak manusia, masa ini otak bersifat plastis dibandingkan dengan orang dewasa sehingga balita sangat terbuka dan peka dalam menerima berbagai macam pembelajaran dan pengayaan baik bersifat positif maupun negatif. Oleh karena itu kita harus memberi masukan dan nilai-nilai yang postiif, menghindari masukan yang bersifat negatif dan sedapat mungkin memberikan asupan gizi yang adekuat, memberikan stimulasi yang baik dan benar, serta memberikan pelayanan kesehatan yang terbaik bagi anak, sehingga tercapai tumbuh kembang yang optimal. ${ }^{1}$

Dalam upaya mengatasi permasalahan gizi buruk dan gizi kurang pada balita, kementerian kesehatan telah menetapkan kebijakan yang komprehensif meliputi pencegahan, promosi/edukasi dan penanggulangan balita gizi buruk. Salah satu upaya pencegahan gizi kurang maupun gizi buruk adalah dilaksanakan melalui pemantauan pertumbuhan dan perkembangan di Posyandu. ${ }^{2}$

Bidan berdasarkan kewenangannya dapat melakukan pemantauan pertumbuhan dan perkembangan pada 
anak balita melalui program pemerintah. Untuk pemantauan tumbuh kembang anak dilakukan sejak usia 3 bulan sampai 72 bulan, yang bertujuan untuk mendeteksi penyimpangan tumbuh kembang serta dapat melakukan intervensi sedini-dininya untuk memperbaiki penyimpangan yang terjadi dan jika perlu dilakukan rujukan sesuai dengan indikasi. ${ }^{3}$

Pengukuran antropometri dapat menggambarkan pertumbuhan anak dan setiap pertanyaan pada KPSP menggambarkan salah satu aspek perkembangan yaitu perkembangan motorik kasar, motorik halus, bicara dan bahasa, serta sosialisasi dan kemandirian. Kuesioner ini dipilih karena penggunaannya mudah, cepat, dapat diterapkan pada sarana kesehatan dasar, dan dapat mengetahui apakah pertumbuhan dan perkembangan anak normal atau terdapat penyimpangan. ${ }^{1}$

Pada penelitian yang dilakukan pada bulan April 2013 di Posyandu Teratai II Kedunglumbu Pasar Kliwon Surakarta. Analisa data dengan menggunakan uji statistik Rank Spearman's. Hasil penelitian menunjukkan ada hubungan yang signifikan antara pertumbuhan balita dengan perkembangan balita. Dari hasil analisis diperoleh nilai $r=0,395$, artinya hubungan pertumbuhan balita dengan perkembangan balita menunjukkan hubungan sedang. ${ }^{4}$

Cakupan DDTK di Surakarta adalah 41,55\%, dimana Kelurahan Mojosongo merupakan salah satu wilayah dengan cakupan DDTK yang masih rendah di Surakarta yaitu sebesar 40\%. Kelurahan Mojosongo memiliki beberapa posyandu dengan cakupan DDTK terendah adalah di posyandu Tawangsari.

Dari studi pendahuluan yang dilakukan dengan kader posyandu, jumlah bayi dan balita di posyandu Tawangsari adalah sekitar 120 bayi dan balita. Di posyandu Tawangsari belum rutin dilakukan pemeriksaan DDTK dan masih terdapat 2 balita dengan kategori gizi kurang.

Berdasarkanuraiandiatastujuan umum pada penelitian ini adalah : Menganalisis hubungan Status GiziDengan Perkembangan Anak Usia35Tahun di Posyandu Tawangsari Mojosongo Jebres Surakarta. Tujuan khusus penelitian ini adalah : Mengetahui Status gizi Anak usia 3 - 5 Tahun, Mengetahui perkembangan anak usia 3 - 5 Tahun, Mengetahui hubungan Status GiziDengan Perkembangan Anak Usia3-5Tahun di Posyandu Tawangsari Mojosongo Jebres Surakarta

\section{Metode Penelitian}

Jenis penelitian ini adalah jenis penelitian kuantitatif korelasional dengan pendekatan cross sectional. Populasi dalam penelitian ini adalah anak usia $3-5$ tahun di posyandu Tawangsari, Mojosongo, Jebres, Surakarta yang berjumlah 74 balita. Sampel dalam penelitian ini terdiri dari 40 balita. teknik sampling yang digunakan adalah simple random sampling yaitu dengan mengacak sederhana (mengundi) daftar nama anak usia $3-5$ tahun di posyandu Tawangsari, Mojosongo, Jebres, Surakarta sebelum penelitian dilakukan.

Instrumen penelitian ini tidak dilakukan validitas dan reliabilitas karena merupakan alat ukur baku. Tabel BB/TB merupakan alat baku dalam mengukur status gizi dari Direktorat Gizi masyarakat (2002) dan Kuesioner Pra Skrening Perkembangan (KPSP) merupakan alat baku pemeriksaan Deteksi Dini Tumbuh kembang dari Depkes RI (2007).

Teknik analisa data pada penelitian ini digunakan untuk mengetahui hubungan status gizi dengan perkembangan. Setelah terkumpul, data dari masing-masing variabel akan dianalisis dengan bantuan program SPSS secara multivariat menggunakan 
chi square. Pengaruh variabel yang diteliti, status gizi terhadap perkembangan pada anak usia $3-5$ tahun menggunakan Odds Ratio (OR) dan hasilnya ditunjukkan oleh nilai $\mathrm{p}$

\section{Hasil Dan Pembahasan}

Pada variabel status gizi menunjukkan bahwa anak usia $3-5$ dengan status gizi kurus sekali sebanyak 1 orang (2,5\%), kurus sebanyak 7 orang $(17,5 \%)$, normal sebanyak 31 orang $(77,5 \%)$ dan gemuk sebanyak 1 orang $(2,5 \%)$

Pada variabel perkembangan menunjukkan bahwa perkembangan pada anak usia 3 - 5 yang tidak sesuai sebanyak 7 orang $(17,5 \%)$ dan sesuai sebanyak 33 orang $(82,5 \%)$.

Hasil penelitian menunjukkan bahwa dari 1 anak dengan status gizi kurus sekali diketahui bahwa perkembangannya tidak sesuai $(2,5 \%) .7$ orang anak dengan status gizi kurus keseluruhannya juga perkembangannya tidak sesuai $(17,5 \%)$. 31 orang anak dengan status gizi normal diketahui bahwa keseluruhannya (77,5\%) perkembangannya sesuai dan sebanyak 1 orang dengan status gizi gemuk diketahui perkembangannya sesuai $(2,5 \%)$.Nilai $p$ value adalah 0.000 berarti terdapat hubungan status gizi dengan perkembangan pada anak usia 3 - 5 tahun.Nilai Odd Ratio variabel status gizi sebesar 2,785 berarti bahwa anak dengan status gizi yang normal memiliki kemungkinan untuk mempunyai perkembangan yang sesuai 2,785 kali lebih besar daripada anak dengan status gizi yang tidak normal.

Nilai $p$ value adalah 0.000 menunjukkan bahwa terdapat hubungan status gizi dengan perkembangan pada anak usia 3 - 5 tahun. Nilai Odd Ratio sebesar 2,785 berarti bahwa anak dengan status gizi yang normal memiliki kemungkinan untuk mempunyai perkembangan yang sesuai 2,785 kali lebih besar daripada anak dengan status gizi yang tidak normal.

Hasil penelitian ini mendukung penelitian dari Sutiari dan Wulandari (2011) dengan hasil bahwa ada hubungan yang signifikan antara status gizi waktu lahir dengan tingkat perkembangan anak usia pra sekolah. ${ }^{5}$ Hasil penelitian ini juga sesuai dengan penelitian yang dilakukan oleh Nyoman Ribek pada tahun 2012 dengan hasil $p=0,000<0,05$ yaitu ada hubungan antara status gizi dengan tingkat perkembangan usia Toddler (12-36 bulan). ${ }^{6}$ dan penelitian dari Lindawati (2013), yang melakukan penelitian pada anak usia pra sekolah dengan menggunakan uji regresi logistik dengan hasil variabel yang paling berhubungan dengan perkembangan anak adalah status gizi. $^{7}$

Penelitian sejenis juga dilakukan oleh (Wauran, C.G, 2016) hasil penelitian menunjukan terdapat hubungan yang bermakna antara status gizi dengan perkembangan motorik kasar pada anak usia 1-3 tahun. Uji statistik chi - square didapatkan hasil $\mathrm{p}$ $=0,006$. Kesimpulan status gizi mempengaruhi perkembangan motorik kasar anak, sehingga untuk mendapatkan perkembangan motorik yang sesuai memerlukan kecukupan gizi yang optimal. ${ }^{8}$

Hasil penelitian sejenis dengan hasil dari 84 anak menunjukkan bahwa terdapat anak dengan status gizi normal sebanyak 69 anak (82,2 \%), kurus sebanyak 12 anak $(14,2 \%)$ dan gemuk sebanyak 3 anak $(3,6 \%)$. Kemudian anak dengan perkembangan normal sebanyak 75 anak $(89,3 \%)$ dan anak dengan perkembangan abnormal sebanyak 9 anak (10,7 \%). Hasil uji statistik menunjukkan koefisien korelasi sebesar 0,225 dengan signifikansi 0,039 ( $\mathrm{p}<$ 0,005). Kesimpulan yang dapat diambil adalah terdapat hubungan positif dan signifikan dengan tingkat korelasi yang rendah antara status gizi dengan 
perkembangan anak usia 2 sampai 3 tahun di Wilayah Kerja Puskesmas Gambirsari Kota Surakarta. ${ }^{9}$

Dalam pertumbuhan dan perkembangan anak memerlukan zat gizi agar proses pertumbuhan dan perkembangan berjalan dengan baik. Zat-zat gizi yang dikonsumi akan berpengaruh pada status gizi. Terpenuhinya gizi yang baik tergantung dari pola asuh gizi yang diberikan oleh orang tua kepada anaknya. Banyak ahli mengatakan pengasuhan anak (child rearing) adalah bagian penting dan mendasar, menyiapkan anak untuk menjadi masyarakat yang baik. Pengasuhan anak disini menunjuk kepada pendidikan umum yang diterapkan dalam pengasuh terhadap anak berupa suatu proses interaksi antara orang tua (pengasuh) dengan anak (yang diasuh). Interaksi tersebut mencakup perawatan seperti mencukupi kebutuhan makan, mendorong keberhasilan dan melindungi, maupun sosialiasi yaitu mengajarkan tingkah laku umum yang diterima oleh masyarakat. ${ }^{10}$

\section{Kesimpulan}

Satus gizi anak usia 3 - 5 Tahundi Posyandu Tawangsari Mojosongo Jebres Surakarta, yaitu kurus sekali sebanyak 1 orang $(2,5 \%)$, kurus sebanyak 7 orang $(17,5 \%)$, normal sebanyak 31 orang $(77,5 \%)$ dan gemuk sebanyak 1 orang $(2,5 \%)$

Perkembangan anak usia $3-5$ Tahun di Posyandu Tawangsari Mojosongo Jebres Surakartayang tidak sesuai sebanyak 7 orang $(17,5 \%)$ dan sesuai sebanyak 33 orang $(82,5 \%)$.

Ada hubungan status gizi dengan perkembangan pada anak usia $3-5$ tahun. Anak yang memiliki status gizi normal mempunyai perkembangan yang sesuai dibandingkan dengan anak dengan status gizi kurus sekali, kurus, dan gemuk. Hubungan tersebut secara statistik signifikan $(\mathrm{OR}=2,785 ; \mathrm{p}=$ $0.000)$

\section{Daftar Pustaka}

[1] Kementrian Kesehatan Republik Indonesia. Pedoman pelaksanaan stimulasi deteksi dan intervensi dini tumbuh kembang anak ditingkat pelayanankesehatan dasar. Jakarta: Departemen Kesehatan Republik Indonesia; 2010.

[2] Kementrian Kesehatan Republik Indonesia, 2011. Modul Pelatihan Penilaian Pertumbuhan Anak. Direktorat Jenderal Bina Gizi dan Kesehatan Ibu dan Anak.Jakarta : Kemenkes RI

[3] Ramli, Agho KE, Inder KJ, Bowe SJ, Jacobs J, Dibley MJ. Prevalence and risk factors for stunting and severe stunting among under-fives in North Maluku province of Indonesia. BMC Pediatrics. 2009; 9: 64.

[4] Rahayu, S. 2014. Pertumbuhan dan Perkembangan Balita di Posyandu Surakarta. Jurnal Terpadu Ilmu Kesehatan vol 3, No 1, Mei 2014, hlm $88-92$

[5]Sutiari, NK dan Wulandari, DAR. 2011. Hubungan Status Gizi Waktu Lahir dengan Pertumbuhan dan Perkembangan Anak Usia Pra Sekolah di Desa Peguyangan Kota Denpasar. Jurnal Ilmu Gizi. Vol 2 No. 2. Hal : $109-117$.

[6] Nyoman Ribek ,Ni Nyoman Pradnya Paramitha Dewi. 2012. Status Gizi Dengan Tingkat Perkembangan Usia Toddler (12 36 Bulan). Jurusan Keperawatan Poltekkes Denpasar

[7] Lindawati. 2013. Faktor-Faktor yang Berhubungan Dengan Perkembangan Motorik Anak Usia Pra Sekolah. Jurusan Keperawatan Poltekkes Kemenkes Jakarta I

[8] Wauran, C.G, Kundre, R, Silolonga, W. 2016. Hubungan 
Status Gizi Dengan Perkembangan Motorik Kasar Pada Anak Usia 1 3 Tahun Di Kelurahan Bitung Kecamatan Amurang Kabupaten

Minahasa Selatan. e-journal Keperawatan (e-Kp) Vol 4 No 2, Juli 2016

[9] Zulaikhah, S. 2010. Hubungan Status Gizi DenGan Perkembangan Anak Usia 2 Sampai 3 Tahun Di Wilayah Kerja Puskesmas Gambirsari Kota Surakarta. Program Studi D IV Kebidanan Fakultas KadokteranUniversitas Sebelas Maret Surakarta

[10] Wong, DL.2009. Pedoman Klinis Keperawatan Pediatrik. Jakarta: EGC 